\title{
Article
}

\section{Teachers' Expectations and Perceptions of the Relevance of Professional Development MOOCs}

\author{
Jaana Kristiina Herranen ${ }^{1, *(\mathbb{D}}$, Maija Katariina Aksela ${ }^{1} \mathbb{C}$, Maya Kaul ${ }^{2} \mathbb{D}$ and Saara Lehto ${ }^{3}$ \\ 1 Department of Chemistry, University of Helsinki, 00100 Helsinki, Finland; maija.aksela@helsinki.fi \\ 2 Division of Education Policy, University of Pennsylvania Graduate School of Education, \\ Philadelphia, PA 19104, USA; mayakaul@upenn.edu \\ 3 Department of Mathematics and Statistics, University of Helsinki, 00100 Helsinki, Finland; \\ saara.lehto@helsinki.fi \\ * Correspondence: jaana.herranen@helsinki.fi
}

check for updates

Citation: Herranen, J.K.; Aksela, M.K.; Kaul, M.; Lehto, S. Teachers' Expectations and Perceptions of the Relevance of Professional Development MOOCs. Educ. Sci. 2021, 11, 240. https://doi.org/ 10.3390/educsci11050240

Academic Editor: Neil Gordon

Received: 9 April 2021

Accepted: 13 May 2021

Published: 17 May 2021

Publisher's Note: MDPI stays neutral with regard to jurisdictional claims in published maps and institutional affiliations.

Copyright: (C) 2021 by the authors. Licensee MDPI, Basel, Switzerland. This article is an open access article distributed under the terms and conditions of the Creative Commons Attribution (CC BY) license (https:/ / creativecommons.org/licenses/by/ $4.0 /)$.

\begin{abstract}
Online professional-development courses such as massive open online courses (MOOCs) could bring relevant content to a wider base of teachers who might not otherwise have access to professional development. However, research on the relevance of such online courses is scarce. The main aim of this study is to investigate the relevance (individual, societal, and vocational) of MOOCs (mostly participatory cMOOCs) from the viewpoint of teachers now and in the future. We examined teachers' expectations and perceptions of 10 courses before $(\mathrm{N}=364)$ and after $(\mathrm{N}=177)$ the courses, using an online questionnaire developed on the basis of relevance theory. According to the results, the studied teachers had positive expectations for the courses in terms of their usefulness for their prospective teaching (especially vocational relevance). Teachers' expectations related to the usefulness of the course for the future (individual and vocational relevance) were most strongly met. Effort put into the course was connected to, for example, how the course improved the teachers' interest. The results of this study indicate that MOOCs can serve as relevant courses for teachers' professional development in science, mathematics, and technology education.
\end{abstract}

Keywords: relevance; online education; MOOC; teachers; professional development; mathematics education; science education

\section{Introduction}

Teachers' ongoing learning is important in promoting their up-to-date knowledge and skills in their field [1-3]. However, teachers' participation in professional-development courses is often challenging, as the courses are usually only organized in some locations, often far away from universities. As a solution, previous research suggested including online courses into teachers' professional programs [4]. This was also studied in the specific context of mathematics and science education [5,6], but more research is needed to understand the degree to which these courses are relevant to teachers. Teachers prefer to have digital tools and optionality used in their training [7]. Massive online open courses (MOOCs) could be a good option to achieve this. However, accessibility alone is insufficient for a successful online course [8]. To be able to offer MOOCs for teachers that they also find relevant for their teaching, more research is needed on the topic.

In science education research, what makes learning relevant for students has been investigated [9]. From a professional-development point of view, it is also highly important to ask what makes learning relevant for teachers. This study, therefore, focuses on the idea of relevance from teachers' point of view. Relevance theory originates from the studies of students' relevance [9]. This study suggests that relevance theory could also be applicable when teachers are studied because related concepts such as interest were also used when learners [10] and teachers [11] were studied. 
Mathematics, science, and technology teacher education in Finland operates through multiple platforms [3], and was more recently expanded to online settings [12,13]. In order to support teachers' professional development (PD), online PD courses (or MOOCs) are organized to cover different areas on science, mathematics, and technology education (see Section 3 for details).

The aim of this study is to investigate the relevance of the MOOC courses from the teachers' viewpoint, from the perspective of relevance theory [9] (see Section 2 for details). We concentrate on teachers' expectations of the relevance of the MOOCs before the courses and their perceptions of the relevance of the MOOCs after the courses (how the teachers' expectations were met in the courses).

The research questions are:

- What were the teachers' expectations about the relevance of the MOOC courses that they attended?

- What were the teachers' perceptions of the relevance of the MOOC courses?

- Was there a connection between teachers' backgrounds and their perceptions of the relevance of the MOOC courses?

The hypothesis was that the teachers would find the courses vocationally relevant at the time and for their prospective teaching.

\section{Background}

\subsection{Relevance of Teachers' Professional Development}

PD programs are essential to educational change [2,14]. The requirements of programs depend on at who the programs are aimed, and how they approach supporting the development of teachers' pedagogical-content knowledge [15]. For example, previous research recommended that primary teachers take courses that support their STEM expertise so that they can integrate disciplines, have an understanding of pedagogical approaches, and be capable of connecting to real-life relevance [16]. It is also important to focus on content that is linked to the teachers' actual teaching, and which promotes active learning, the support for collaboration, models and modeling of effective practice, expert support and feedback, and reflection through sustained opportunities for professional learning [17].

This research utilizes the relevance theory by Stuckey et al. [9], but earlier work from Van Aalsvoort (2004) also quite similarly described the concept of relevance [18]. Relevance was also described as a synonym for motivation and interest [19]. The main dimensions of Stuckey's relevance model are: (i) individual, (ii) societal, and (iii) vocational [9]. Individual relevance consists of aspects such as "satisfying curiosity and interest" and "skills for coping with personal life in future" $[9,20]$. Societal relevance is defined by aspects related to persons' behavior in the society, responsibly and through their own interests. Vocational relevance consists of orienting towards, qualifying for, and getting a job, contributing to socioeconomic growth. The present-future range refers to skills and actions now (e.g., satisfying interests, finding their own place) and in the future (e.g., acting responsibly, promoting own interests). The intrinsic-extrinsic range presents relevance from the viewpoint of the learners' interests (intrinsic relevance) and from the viewpoint of societal expectations (extrinsic relevance).

The components of relevance were originally formulated on the basis of studies of students' relevance [9]. In this study, we applied that theory to teachers' professional development.

\subsection{Professional Development Using MOOCs as Online Learning Platforms}

MOOCs are forms of online learning that are designed to be accessible to all [20-22]. Additionally, MOOCs can help address typical barriers that teachers face in seeking professional development, such as the lack of local offerings, which do not conflict with their work schedules, and the lack of relevant PD [7]. A 2019 systematic review of MOOCs found that $87.5 \%$ of 46 examined programs were successful in promising both equity and social inclusion [23]. However, there are challenges in ensuring that MOOCs are accessible 
to all and not just those who might already have access to such education [24]. In addition, questions related to the effectiveness of the MOOCs were raised, such as whether they offer teachers a possibility for transformative learning [25].

As such, MOOCs have been studied and implemented as a potential lever to help expand access among teachers globally to high-quality PD. Previous PD MOOCs are organized around topics left undercovered in traditional PD, such as topics related to sustainability [5] or social media as a pedagogical tool [26]. These studies provide emerging evidence supporting that MOOCs could be particularly effective as a method for providing teachers with up-to-date content knowledge to which they may otherwise not have access.

Despite the growing use of MOOCs in PDs [27], they have largely not been studied in the context of relevance. Previous studies examined how to design MOOCs and pedagogy, teachers' interest and motivation, and MOOC effectiveness [27]. PD MOOCs were mostly studied from the viewpoint of concepts related to relevance, such as teachers' views [27] and experiences [28]. According to the study by Koukis and Jimoyiannis [27], a successful PD MOOC connects the course and the actual classroom, has concrete learning aims, supports teacher collaboration, and creates a learning community. In Wambugu's study, the participants found the designed MOOC to be interesting, appealing, and flexible, and they learned from each other [28].

How people learn through MOOCs also depends on the participants. In an MOOC course for undergraduate students, goal setting and task interest were the main predictors of their MOOC completion [29]. To support participation and learning, MOOC developers sometimes refer to "cMOOCs" as those that include collaboration and focus on participants building connections with other participants and the lecturer [30]. "xMOOCs", on the other hand, are those that aim to offer high-quality content delivery for the participants and focus less on collaboration among participants [30]. While xMOOC pedagogics have been criticized, they also took a research-based approach to improving their completion rates [31]. A recent case study reported that high-impact online teaching practices included both effective content delivery and the possibility for students to be supported for their learning and participation [32]. In addition, to support communication, synchronous (real-time) communication is used in online learning, as opposed to or together with asynchronous learning [33]. A cMOOC can include both types of communication.

Studies related to relevance of MOOC for teachers show that MOOCs are useful in scaling up PDs and removing participant barriers [7]. In a study by Powell and Bodur [8], the relevancy of their online PD course was defined by its ability to attend to teachers' individual professional learning needs. According to their teacher interviews, teachers saw the lack of personalization as inhibiting the relevance of the course. The more experienced teachers may have different needs for the course than those of less experienced ones.

It is important to study teachers' MOOC expectations and perceptions of relevance because teachers' expectations and perceptions of relevance could be useful in improving PD MOOCs.

\section{Context}

\subsection{National LUMA FINLAND Program and MOOCs}

The MOOCs studied in this research were developed as part of the national LUMA FINLAND Program (2014-2019). This was a development program for inservice teacher education funded by the Ministry of Education and Culture of Finland, and implemented via the LUMA Centre Finland network. The aim of the program was to enhance interest in science, mathematics, and technology among 6-16-year-old students by developing and studying new modes of professional development for preparing teachers to engage in the 21st century STEM curriculum. The program consisted of a development phase (2014-2016), during which new research-based teaching methods were developed in cooperation with inservice teachers, and university experts and researchers; and a dissemination phase (2017-2019), during which nationwide inservice teacher education was organized and implemented. 
One of the goals of the program was to reach teachers from all around the country, including municipalities farther away from universities and larger cities. Towards this aim, 13 MOOCs were designed as part of the program as a means of disseminating the educational products developed in the program. The program was both focused on producing MOOCs, and developing and offering PD for teachers. However, this study focuses on those MOOCs. The use of MOOCs was new for PD in the LUMA Finland setting. This is why we were interested to study the relevance of those MOOCs. Dissemination was successful, and the program reached approximately $80 \%$ of Finland's 311 municipalities. A significant part of the success was driven by the reach of the MOOCs. Several of them are still operational, and material from the MOOCs continues to be offered through videos.

Ten out of 13 courses of the national LUMA Finland program are included in this research (i.e., those that did not have another research focus). Of the 10 MOOCs in this study, 3 concentrated on project learning and nonformal education in science and mathematics, 2 on mathematics education, 3 on programming and game programming, 1 on school-business cooperation in science and mathematics education, and 1 on work-life knowledge in science and mathematics education (see Appendix A). MOOCs were aimed at different teaching levels covering preschool, primary education, and lower secondary education with a slight emphasis on the higher levels.

The MOOCs were mainly cMOOCs (rather than XMOOCs), which means that they offered active participation and collaboration within the courses, and also synchronous communication, in particular during the dissemination phase of the development program. Some of the courses were webinars, so there was less collaboration (see Appendix A).

\subsection{Three MOOC Examples}

As an example of the format and development process of these MOOCs, we describe three MOOCs with different development program areas: 'Basics of game programming with Unity', 'Everyday Phenomena and Projects in STEAM Education', and 'Towards the Better Understanding of Numbers and Equations'.

Each of these three MOOCs had different aims. They were either quite concrete, as in the 'Basics of game programming with Unity', in which the aim was to familiarize the participants to (game) programming, or more abstract, as in 'Everyday Phenomena and Projects in STEAM Education', in which the aim was to support and inspire teachers to carry out integrated and phenomenon-based science education through project learning. Phenomenon-based learning refers to the pedagogy of viewing learning as a whole, taking into consideration the natural phenomenon of the subject being taught, the students' active learning process, and the teacher and their reflection [34]. 'Towards Better Understanding of Numbers and Equations' had both types of aims. The aim was to open new perspectives for teachers on how to examine mathematical learning and teaching with "new eyes" through developing flexible mathematical and algebraic thinking, and to provide concrete tools to do so.

The courses were applied to teaching in school, as the participants were given examples that they could use in their own teaching. In 'Basics of game programming with Unity', students participated in the course with their own teacher. Curriculum connection was also often emphasized, as in 'Everyday Phenomena and Projects in STEAM Education', where the course material was planned according to the curriculum. The material had practical examples, including, e.g., other teachers' teaching examples, tips for evaluation, examples of everyday phenomena that could be used in phenomenon-based learning, a model for inquiry-based teaching, examples for collaboration, science drama, and the use of ICT. There was also a possibility to plan an integrative-teaching sequence with other participants with the course teacher's support.

Each course had a length of 10-50 h depending on format and aims. Most of the courses allowed for participants to complete the material in their own time and at their own place; therefore, the instructor was not available to support all the time. As an exception, 'Basics of game programming with Unity' was offered within a certain time frame. 
The courses included text, pictures, and videos that the participants were provided to perform tasks. Participants were asked to watch videos, read texts, write texts (such as practical work plans and learning diaries), take tests, and participate in discussions. The courses were c-type MOOCs, including interaction with the other participants and the course developers.

Each course was developed through a slightly different process. 'Basics of game programming with Unity' began as a coding camp, followed by a course, and lastly a web version, with several iteration phases. Collaboration among course developers was central to the development process of this course. In 'Towards Better Understanding of Numbers and Equations', three course developer teams first produced their own material and approaches. An algebraic path from preschool to secondary school was created through collaboration among developers. Live training was first carried out, and the MOOC was then developed through peer support, and dividing the tasks on the basis of skills and available time. 'Everyday Phenomena and Projects in STEAM Education' was developed together with teachers, and thereby doubled as a year-long inservice training sequence for the teachers. The final MOOC course was a result of further development through teacher and student feedback, as the course was offered to teachers and students with different formats.

\section{Research Method}

This is a quantitative-survey study for which an online questionnaire was developed for teachers on the basis of the theory of relevance [9]. The teachers were asked about their perceptions of the relevance of MOOCs individually, societally, and vocationally. For the purpose of applying the theory of relevance for teachers, the dimensions of the model were slightly modified. The developers of the model explained that the different dimensions could be weighted depending on the learners' age, for example [9]. Keeping that in mind, the temporal range is less clear when we talk about teachers because they have already chosen their careers. They can, however, approach professional-development course content from the viewpoint of their current teaching and their prospective teaching. This is because the demands for their prospective teaching might be different than the demands that they have now, as the world is constantly changing. Additionally, external and internal demands can be quite different depending on how old the study participants are. Some of the aspects might overlap, such as the individual dimension with the intrinsic end of the intrinsic-extrinsic range, and the societal dimension with the extrinsic end of the intrinsicextrinsic range. This confusion led us to construct the teacher questionnaire without the intrinsic-extrinsic range. However, we kept the present-future range. In addition, the temporal component was further strengthened by administering the prequestionnaire (focused on teachers' expectations before the course) and postquestionnaire (focused on teachers' perceptions after the course).

Teachers answered both the pre- and the postquestionnaire. The prequestionnaire was aimed at capturing the teachers' expectations for the course for which they registered $(\mathrm{n}=364)$. The postquestionnaire was aimed at examining how expectations were met in the course $(n=177)$. Participants were asked to answer the postquestionnaire immediately after completing the course. The validity of the survey was examined by principal-component analysis (PCA) using autumn 2018 data (165 responses in prequestionnaire and 88 responses in postquestionnaire). Items in the questionnaire were loaded onto two components (with Cronbach's alpha values $>0.7$ ) in the pre- and postquestionnaires. The requirement for conducting PCA was also estimated by running Kaiser-Mayer-Olkin measure of sampling adequacy, which was 0.799 , and Bartlett's test of sphericity $(p<0.001)$.

The components onto which the questionnaire items were loaded were:

(i) socioindividual relevance: items related to individual and societal relevance; and

(ii) vocational relevance: items related to usefulness in the future/for the vocation.

However, not all items were loaded onto the components; thus, those items were individually handled. 
Correlations were counted with SPSS using Spearman's correlations. Correlations were counted with teachers' background items and relevance: both relevance components and individual relevance items in the questionnaire.

\section{Participant Backgrounds}

The prequestionnaire was answered by 364 MOOC participants, and the postquestionnaire by 177 participants. Of the respondents, $308(84.62 \%)$ in the prequestionnaire were women and $54(14.84 \%)$ were men (two of the respondents did not wish to indicate their gender). Participants' age, teaching experience, and teaching level are shown in Table 1.

Table 1. Age, teaching experience, and teaching level of respondents.

\begin{tabular}{ccc}
\hline Age (y) & preQ n (\%) & postQ n (\%) \\
\hline $18-25$ & $37(10.16 \%)$ & $18(10.17 \%)$ \\
$26-35$ & $89(24.45 \%)$ & $34(19.21 \%)$ \\
$36-45$ & $96(26.37 \%)$ & $67(37.85 \%)$ \\
$46-55$ & $93(25.55 \%)$ & $43(24.29 \%)$ \\
$56-65$ & $49(13.46 \%)$ & $15(8.47 \%)$ \\
Over 65 & $0(0 \%)$ & $0(0 \%)$ \\
\hline Teaching experience (y) & preQ n (\%) & postQ n (\%) \\
\hline $0-2$ & $70(19.23 \%)$ & $29(16.38 \%)$ \\
$2-5$ & $58(15.93 \%)$ & $29(16.38 \%)$ \\
$5-10$ & $63(17.31 \%)$ & $35(19.77 \%)$ \\
$10-20$ & $86(23.63 \%)$ & $49(27.68 \%)$ \\
Over 20 & $87(23.90 \%)$ & $35(19.77 \%)$ \\
\hline Teaching level 1 & preQ $\mathbf{n} \mathbf{( \% )}$ & postQ $\mathbf{n ~ ( \% )}$ \\
\hline Early-childhood education & $15(4.12 \%)$ & $15(8.47 \%)$ \\
Preschool & $41(11.26 \%)$ & $23(12.99 \%)$ \\
Primary education, Levels 1-2 & $85(23.35 \%)$ & $45(25.42 \%)$ \\
Primary education, Levels 3-6 & $94(25.82 \%)$ & $42(23.73 \%)$ \\
Lower secondary school & $159(43.68 \%)$ & $75(42.37 \%)$ \\
Upper secondary school (gymnasium) & $70(19.23 \%)$ & $31(17.51 \%)$ \\
Upper secondary school (vocational school) & $10(2.75 \%)$ & $2(1.13 \%)$ \\
Higher education & $7(1.92 \%)$ & $2(1.13 \%)$ \\
Primary-school student teacher & $25(6.87 \%)$ & $28(15.82 \%)$ \\
Secondary-school student teacher & $31(8.52 \%)$ & $11(6.21 \%)$ \\
Other 2 & $18(4.95 \%)$ & $6(3.39 \%)$ \\
\hline
\end{tabular}

${ }^{1}$ There are some overlapping responses because teachers might teach several grades. ${ }^{2}$ Other teaching levels include mainly special-education teachers and adult educators.

\section{Results}

\subsection{Teachers' Expectations for PD Courses}

The studied teachers had positive expectations for the PD courses. When asked about their expectations, most of the teachers' responses varied between agree and fully agree (see Table 2). Teachers expected that the course would be especially useful for their prospective teaching (see Items 3, 7, 8, and 9 in Table 1). Teachers, however, had the lowest expectations for the course's influence on their appreciation for mathematics, science, technology, or their teaching (Item 6).

\subsection{How Teachers' Expectations Were Met in the PD Courses}

After completing the course, teachers considered the courses to be vocationally relevant: almost all teachers reported that they planned to put what they had learned to use, irrespective of the course that they had completed. However, teachers' responses to the postquestionnaire indicated that the courses did not fully meet their original expectations, which were very high. Teachers' expectations to learn about collaboration and significance 
were the farthest from being met (see Items 3, 7, and 9 in Table 3). Teachers also had big hopes for the courses related to those aspects, as Table 2 shows.

Table 2. Teachers' expectations of the relevance of MOOCs before the course.

\begin{tabular}{|c|c|c|c|c|c|c|c|}
\hline Question & 5 & 4 & 3 & 2 & 1 & Mean & SD \\
\hline \multicolumn{8}{|c|}{ Individual relevance } \\
\hline $\begin{array}{l}\text { 1. I hope that the course will improve my interest about } \\
\text { mathematics, science, technology and their teaching }\end{array}$ & $\begin{array}{c}201 \\
(55.1 \%)\end{array}$ & $\begin{array}{c}123 \\
(33.7 \%)\end{array}$ & $\begin{array}{c}33 \\
(9.0 \%)\end{array}$ & $\begin{array}{c}5 \\
(1.1 \%)\end{array}$ & $\begin{array}{c}3 \\
(0.8 \%)\end{array}$ & 4.40 & 0.78 \\
\hline $\begin{array}{l}\text { 2. I hope that I will learn to understand more about } \\
\text { mathematics, science, technology and their teaching }\end{array}$ & $\begin{array}{c}226 \\
(61.9 \%)\end{array}$ & $\begin{array}{c}110 \\
(30.1 \%)\end{array}$ & $\begin{array}{c}24 \\
(6.6 \%)\end{array}$ & $\begin{array}{c}4 \\
(1.1 \%)\end{array}$ & $\begin{array}{c}1 \\
(0.3 \%)\end{array}$ & 4.53 & 0.69 \\
\hline $\begin{array}{l}\text { 3. I hope that I will learn things that are useful for me } \\
\text { in the future }\end{array}$ & $\begin{array}{c}305 \\
(83.6 \%)\end{array}$ & $\begin{array}{c}52 \\
(14.3 \%)\end{array}$ & $3(0.8 \%)$ & $\begin{array}{c}2 \\
(0.6 \%)\end{array}$ & $\begin{array}{c}3 \\
(0.8 \%)\end{array}$ & 4.79 & 0.56 \\
\hline \multicolumn{8}{|c|}{ Societal relevance } \\
\hline $\begin{array}{l}\text { 4. I hope that I will learn new things about collaboration with } \\
\text { my colleagues and other stakeholders }\end{array}$ & $\begin{array}{c}160 \\
(43.8 \%)\end{array}$ & $\begin{array}{c}150 \\
(41.1 \%)\end{array}$ & $\begin{array}{c}47 \\
(12.9 \%)\end{array}$ & $\begin{array}{c}5 \\
(1.1 \%)\end{array}$ & $\begin{array}{c}3 \\
(0.8 \%)\end{array}$ & 4.25 & 0.79 \\
\hline $\begin{array}{l}\text { 5. I hope that I will get information about the significance of } \\
\text { mathematics, science, technology, or their teaching } \\
\text { for the society }\end{array}$ & $\begin{array}{c}156 \\
(42.7 \%)\end{array}$ & $\begin{array}{c}147 \\
(40.3 \%)\end{array}$ & $\begin{array}{c}49 \\
(13.4 \%)\end{array}$ & $\begin{array}{c}11 \\
(3.0 \%)\end{array}$ & $\begin{array}{c}2 \\
(0.6 \%)\end{array}$ & 4.21 & 0.83 \\
\hline $\begin{array}{l}\text { 6. I hope that the course will improve my appreciation over } \\
\text { mathematics, science, technology or their teaching }\end{array}$ & $\begin{array}{c}143 \\
(39.2 \%)\end{array}$ & $\begin{array}{c}128 \\
(35.1 \%)\end{array}$ & $\begin{array}{c}78 \\
(21.4 \%)\end{array}$ & $\begin{array}{c}12 \\
(3.3 \%)\end{array}$ & $\begin{array}{c}4 \\
(1.1 \%)\end{array}$ & 4.08 & 0.91 \\
\hline \multicolumn{8}{|c|}{ Vocational relevance } \\
\hline $\begin{array}{l}\text { 7. I hope that I will learn in the course useful skills or } \\
\text { information for my own teaching }\end{array}$ & $\begin{array}{c}327 \\
(89.6 \%)\end{array}$ & $\begin{array}{c}31 \\
(8.5 \%)\end{array}$ & $\begin{array}{c}3 \\
(0.8 \%)\end{array}$ & $\begin{array}{c}0 \\
(0 \%)\end{array}$ & $\begin{array}{c}4 \\
(1.1 \%)\end{array}$ & 4.86 & 0.52 \\
\hline $\begin{array}{l}\text { 8. I hope that the course will widen my perspectives about } \\
\text { mathematics, science, technology or their teaching }\end{array}$ & $\begin{array}{c}267 \\
(73.2 \%)\end{array}$ & $\begin{array}{c}79 \\
(21.6 \%)\end{array}$ & $\begin{array}{c}15 \\
(4.1 \%)\end{array}$ & $\begin{array}{c}0 \\
(0 \%)\end{array}$ & $\begin{array}{c}4 \\
(1.1 \%)\end{array}$ & 4.66 & 0.66 \\
\hline $\begin{array}{l}\text { 9. I hope that the course will affect positively into my } \\
\text { prospective teaching }\end{array}$ & $\begin{array}{c}314 \\
(86.0 \%)\end{array}$ & $\begin{array}{c}43 \\
(11.8 \%)\end{array}$ & $\begin{array}{c}4 \\
(1.1 \%)\end{array}$ & $\begin{array}{c}0 \\
(0 \%)\end{array}$ & $\begin{array}{c}4 \\
(1.1 \%)\end{array}$ & 4.82 & 0.55 \\
\hline
\end{tabular}

Table 3. Teachers' perceptions of the relevance of MOOC courses.

\begin{tabular}{|c|c|c|c|c|c|c|c|}
\hline Question & 5 & 4 & 3 & 2 & 1 & Mean & SD \\
\hline \multicolumn{8}{|c|}{ Individual relevance } \\
\hline $\begin{array}{l}\text { 1. The course improved my interest about mathematics, } \\
\text { science, technology and their teaching }\end{array}$ & $\begin{array}{c}78 \\
(44.1 \%)\end{array}$ & $\begin{array}{c}78 \\
(44.1 \%)\end{array}$ & $\begin{array}{c}16 \\
(9.0 \%)\end{array}$ & $\begin{array}{c}3 \\
(1.7 \%)\end{array}$ & $\begin{array}{c}2 \\
(1.1 \%)\end{array}$ & 4.28 & 0.79 \\
\hline $\begin{array}{l}\text { 2. I learned to understand more about mathematics, science, } \\
\text { technology and their teaching }\end{array}$ & $\begin{array}{c}59 \\
(33.3 \%)\end{array}$ & $\begin{array}{c}83 \\
(46.9 \%)\end{array}$ & $\begin{array}{c}29 \\
(16.4 \%)\end{array}$ & $\begin{array}{c}4 \\
(2.3 \%)\end{array}$ & $\begin{array}{c}2 \\
(1.1 \%)\end{array}$ & 4.09 & 0.83 \\
\hline 3. I learned things that are useful for me in the future & $\begin{array}{c}117 \\
(66.1 \%)\end{array}$ & $\begin{array}{c}52 \\
(29.4 \%)\end{array}$ & $5(2.8 \%)$ & $\begin{array}{c}2 \\
(1.1 \%)\end{array}$ & $(0.6 \%)$ & 4.59 & 0.66 \\
\hline \multicolumn{8}{|c|}{ Societal relevance } \\
\hline $\begin{array}{l}\text { 4. I learned new things about collaboration with my } \\
\text { colleagues and other stakeholders }\end{array}$ & $\begin{array}{c}47 \\
(26.6 \%)\end{array}$ & $\begin{array}{c}76 \\
(42.9 \%)\end{array}$ & $\begin{array}{c}33 \\
(18.6 \%)\end{array}$ & $\begin{array}{c}17 \\
(9.6 \%)\end{array}$ & $\begin{array}{c}4 \\
(2.3 \%)\end{array}$ & 3.82 & 1.01 \\
\hline $\begin{array}{l}\text { 5. I got information about the significance of mathematics, } \\
\text { science, technology, or their teaching for the society }\end{array}$ & $\begin{array}{c}36 \\
(20.3 \%)\end{array}$ & $\begin{array}{c}77 \\
(43.5 \%)\end{array}$ & $\begin{array}{c}43 \\
(24.3 \%)\end{array}$ & $\begin{array}{c}15 \\
(8.5 \%)\end{array}$ & $\begin{array}{c}6 \\
(3.4 \%)\end{array}$ & 3.69 & 1.00 \\
\hline $\begin{array}{l}\text { 6. The course improved my appreciation over mathematics, } \\
\text { science, technology or their teaching }\end{array}$ & $\begin{array}{c}56 \\
(31.6 \%)\end{array}$ & $\begin{array}{c}79 \\
(44.6 \%)\end{array}$ & $\begin{array}{c}33 \\
(18.6 \%)\end{array}$ & $\begin{array}{c}6 \\
(3.4 \%)\end{array}$ & $\begin{array}{l}3 \\
(1.7 \%)\end{array}$ & 4.01 & 0.89 \\
\hline \multicolumn{8}{|c|}{ Vocational relevance } \\
\hline 7. I learned useful skills or information for my own teaching & $\begin{array}{c}120 \\
(67.8 \%)\end{array}$ & $\begin{array}{c}48 \\
(27.1 \%)\end{array}$ & $6(3.4 \%)$ & $\begin{array}{c}2 \\
(1.1 \%)\end{array}$ & $\begin{array}{c}1 \\
(0.6 \%)\end{array}$ & 4.60 & 0.67 \\
\hline $\begin{array}{l}\text { 8. The course widened my perspectives about mathematics, } \\
\text { science, technology or their teaching }\end{array}$ & $\begin{array}{c}79 \\
(44.6 \%)\end{array}$ & $\begin{array}{c}74 \\
(41.8 \%)\end{array}$ & $\begin{array}{c}21 \\
(11.9 \%)\end{array}$ & $\begin{array}{c}1 \\
(0.6 \%)\end{array}$ & $\begin{array}{c}2 \\
(1.1 \%)\end{array}$ & 4.28 & 0.78 \\
\hline 9. The course affected positively into my prospective teaching & $\begin{array}{c}116 \\
(65.5 \%)\end{array}$ & $\begin{array}{c}52 \\
(29.4 \%)\end{array}$ & $7(4.0 \%)$ & $\begin{array}{c}1 \\
(0.6 \%)\end{array}$ & $\begin{array}{c}1 \\
(0.6 \%)\end{array}$ & 4.59 & 0.65 \\
\hline
\end{tabular}

When we studied the connections between teachers' backgrounds and their perceptions of the relevance of the MOOC courses, we found correlations between relevance and 
background items. The studied background items were teachers' teaching experience, age, and effort put into the course.

Relevance (socioindividual relevance F1 and vocational relevance F2) correlated with teaching experience: the more experienced teachers were, the more relevant they thought the MOOC course was (see Table 4). Experience also correlated with Items R1, R2, R3, R6, R8, and R9. Age correlated with interest, understanding, and appreciation: older teachers considered the course to be more relevant in terms of raising their own interest, understanding, and appreciation for mathematics, science, technology, or their teaching (Items R1, R2, and R6). Effort put into the course correlated with interest and the broadening of perspectives (Items R1 and R8).

Table 4. Correlation of relevance items with teachers' background. Exp = experience, age = teachers' age, and eff = effort. R1-R9 are individual relevance items, F1 is societal and individual relevance, and F2 is vocation of relevance. Spearman's correlation coefficient was used with two-tailed significance, $\mathrm{n}=177$.

\begin{tabular}{|c|c|c|c|c|}
\hline & & $\operatorname{Exp}$ & Age & Eff \\
\hline & & $\begin{array}{l}\text { cc. } \\
\text { sig. }\end{array}$ & $\begin{array}{l}\text { cc. } \\
\text { sig. }\end{array}$ & $\begin{array}{l}\text { cc. } \\
\text { sig. }\end{array}$ \\
\hline \multirow{6}{*}{ Individual relevance } & \multirow{2}{*}{ R1 } & $0.338^{* *}$ & $0.325^{* *}$ & $0.167^{*}$ \\
\hline & & 0.000 & 0.000 & 0.026 \\
\hline & \multirow{2}{*}{$\mathrm{R} 2$} & $0.215^{* *}$ & $0.203^{* *}$ & 0.108 \\
\hline & & 0.004 & 0.007 & 0.153 \\
\hline & \multirow{2}{*}{ R3 } & $0.149 *$ & 0.048 & 0.133 \\
\hline & & 0.048 & 0.526 & 0.78 \\
\hline \multirow{4}{*}{ Social relevance } & \multirow{2}{*}{$\mathrm{R} 4$} & 0.087 & -0.022 & 0.086 \\
\hline & & 0.248 & 0.774 & 0.257 \\
\hline & \multirow{2}{*}{ R5 } & 0.079 & 0.039 & 0.101 \\
\hline & & 0.293 & 0.603 & 0.179 \\
\hline \multirow{8}{*}{ Vocational relevance } & \multirow{2}{*}{ R6 } & $0.151 *$ & $0.152 *$ & 0.047 \\
\hline & & 0.045 & 0.044 & 0.534 \\
\hline & \multirow{2}{*}{ R7 } & 0.094 & 0.022 & 0.094 \\
\hline & & 0.214 & 0.772 & 0.215 \\
\hline & \multirow{2}{*}{ R8 } & 0.185 * & 0.085 & $0.155^{*}$ \\
\hline & & 0.014 & 0.263 & 0.039 \\
\hline & \multirow{2}{*}{ R9 } & $0.179 *$ & 0.134 & 0.120 \\
\hline & & 0.017 & 0.076 & 0.113 \\
\hline \multirow{2}{*}{ Socioindividual relevance } & \multirow{2}{*}{ F1 } & 0.149 * & 0.091 & 0.128 \\
\hline & & 0.048 & 0.226 & 0.090 \\
\hline \multirow{2}{*}{ Vocational relevance } & \multirow{2}{*}{$\mathrm{F} 2$} & $0.176^{*}$ & 0.079 & 0.127 \\
\hline & & 0.019 & 0.298 & 0.091 \\
\hline
\end{tabular}

* Correlation significant at the 0.05 level (2-tailed). ${ }^{* *}$ Correlation significant at the 0.01 level (2-tailed).

\section{Discussion and Conclusions}

In order to improve mathematics, science, and technology teaching through MOOCs, MOOCs need to be accessible [24]. A successful MOOC is also relevant to teachers, as suggested in this research and before in terms of teachers' professional development in general [16]. The studied teachers had big expectations for the courses in terms of their usefulness for their prospective teaching, and those expectations were close to being met. More precisely, teachers' expectations for collaboration and science, mathematics, and technology teaching were the closest of being met. Collaboration with colleagues was an important component of a successful MOOC [27]. Therefore, a MOOC that is collaborative could be created. Connectivist MOOCs (cMOOCs) are especially concentrated on active participation and connecting with other participants and the teachers [35].

Teachers' effort put into a course was associated with the degree to which they reported that the course improved their interest. The more time one puts into a course, the more interested one could be. However, because correlation was measured and not causality, 
interest could also be awakened early on in the course, which makes teachers invest time during the course. Teachers could be encouraged to invest more time in a course by making the courses personally interesting to them (individual relevance).

This study also indicated that teachers' perceived relevance was connected to their experiences. More experienced teachers considered the courses to be more relevant. Therefore, PD MOOCs could be personalized for novice and more experienced teachers. This resonates with earlier findings that teachers find MOOCs to be less relevant when they lack the ability to personalize their learning [8].

The survey revealed aspects related to measuring teachers' relevance: vocational relevance formed its own component. Thus, relevance theory appears to be different in students vs. teachers. For teachers, individual and societal relevance are closely connected, whereas vocational relevance appears to be a separate aspect of relevance. According to the original model [9], vocational relevance (and other aspects of relevance) has a presentfuture axis. For students, present vocational aspects orient towards the future (passing exams and orienting towards a future career). Teachers, on the other hand, are already living that future by having chosen a teacher career. For them, a course can provide ideas for their future, and through giving ideas and skills that they can use in their prospective teaching. According to this study, the teachers found the courses relevant in that sense. A relevant PD course could be looking at teaching practices now and for the future, according to the idea of lifelong learning. That approach was used in our exemplary courses. Due to differences in students' and teachers' experienced relevance, the relevance instrument could be modified if teachers' relevance instead of that of students is measured. We presented one possible instrument in this paper.

To further develop this instrument, the internal-external range could be taken into account. Teacher's intrinsic expectations affect how they learn, and external expectations (from society and through national curricula) affect teachers' participation in PDs and MOOCs, and the need to develop PDs and MOOCs for teachers. That kind of framework could describe both teachers' external and internal expectations, and society's expectations for, e.g., universities to develop PDs and MOOCs. The internal-external range could be taken into account by including items that concentrate on, e.g., teachers' expectations and perceptions related to external and internal demands. In addition, there are probably other important aspects to still consider, such as teachers' digital competences and orientation towards life-long learning. The effect of the course developers could also be taken into account.

The results of this study indicate that MOOCs could serve as relevant courses for teachers' professional development in science, mathematics, and technology education. Even if this research does not clearly indicate that MOOCs would be more relevant than traditional PD courses are, PD MOOCs provide training to a wider audience, which could make them worth developing and utilizing. The given results encourage continuing the design of relevant cMOOCs for teachers in future research in the topic.

Author Contributions: Conceptualization, M.K.A., M.K. and S.L.; Data curation, J.K.H.; Formal analysis, J.K.H.; Funding acquisition, M.K.A.; Investigation, J.K.H.; Methodology, J.K.H., M.K.A., M.K. and S.L.; Project administration, M.K.A.; Software, J.K.H., M.K. and S.L.; Supervision, M.K.A.; Validation, J.K.H.; Visualization, J.K.H.; Writing—original draft, J.K.H., M.K.A., M.K. and S.L.; Writing-review \& editing, J.K.H., M.K.A., M.K. and S.L. All authors have read and agreed to the published version of the manuscript.

Funding: Open access funding provided by University of Helsinki.

Institutional Review Board Statement: Not applicable.

Informed Consent Statement: Informed consent was obtained from all subjects involved in the study.

Data Availability Statement: Not applicable. 
Acknowledgments: We would like to thank the Ministry of Education and Culture of Finland for funding the LUMA FINLAND program and Veera Uusi-Äijö for assisting to finalize this paper. Open access funding provided by University of Helsinki.

Conflicts of Interest: The authors declare no conflict of interest.

\section{Appendix A}

Table A1. MOOC courses and number of questionnaire respondents.

\begin{tabular}{|c|c|c|}
\hline & \multicolumn{2}{|c|}{ Number of Respondents (\%) } \\
\hline & preQ & postQ \\
\hline $\begin{array}{c}\text { Arjen ilmiöitä ja monialaisia projekteja LUMA-aineiden } \\
\text { opetuksessa (Everyday Phenomena and Projects in STEAM } \\
\text { Education) }\end{array}$ & $28(7.7 \%)$ & $83(46.9 \%)$ \\
\hline GeoGebra opetuksessa (GeoGebra in Teaching) & $106(29.1 \%)$ & $50(28.3 \%)$ \\
\hline $\begin{array}{c}\text { Javan perusteita lyhyesti-webinaari } \\
\text { (Java Basics in Short Webinar) }\end{array}$ & $9(2.5 \%)$ & - \\
\hline $\begin{array}{l}\text { Matematiikka ja luonnontieteet yhteiskunnassa-verkkokurssi } \\
\text { koulu-yritysyhteistyöstä (Science and mathematics in } \\
\text { society-An Online Course On School-Business Cooperation) }\end{array}$ & $11(3.0 \%)$ & - \\
\hline $\begin{array}{l}\text { MOOC-koulutus aiheesta peliohjelmoinnin alkeet Unitylla } \\
\text { (Basics of game programming with Unity) }\end{array}$ & $8(2.2 \%)$ & $3(1.7 \%)$ \\
\hline $\begin{array}{c}\text { Ohjelmoinnin perusteita Pulmaario-tehtävien } \\
\text { kautta—webinaari (webinar: Programming Basics Through } \\
\text { "Pulmaario" Exercises) }\end{array}$ & $17(4.7 \%)$ & $3(1.7 \%)$ \\
\hline $\begin{array}{l}\text { Projektityöskentely matematiikan opetuksessa (project Work in } \\
\text { Mathematics Education) }\end{array}$ & $13(3.4 \%)$ & $1(0.6 \%)$ \\
\hline Tiede- ja teknologiakasvatus (science education) & $50(13.7 \%)$ & $6(3.4 \%)$ \\
\hline $\begin{array}{c}\text { Työelämätieto LUMA-aineiden opetuksessa (Work-Life } \\
\text { Knowledge in STEM Eduation) }\end{array}$ & $3(0.8 \%)$ & - \\
\hline $\begin{array}{l}\text { Vahvuutta lukukäsitteeseen-ymmärrystä yhtälönratkaisuun } \\
\text { (Towards the Better Understanding of Numbers and Equations) }\end{array}$ & $119(32.7 \%)$ & 31 (17.5\%) \\
\hline Total & 364 & 177 \\
\hline
\end{tabular}

\section{References}

1. OECD. TALIS 2018 Results (Volume II): Teachers and School Leaders as Valued Professionals; OECD Publishing: Paris, France, 2020. [CrossRef]

2. Kaiser, G.; König, J. Competence Measurement in (Mathematics) Teacher Education and Beyond: Implications for Policy. High. Educ. 2019, 32, 597-615. [CrossRef]

3. Lavonen, J.; Mahlamäki-Kultanen, S.; Vahtivuori-Hänninen, S.; Mikkola, A. A Collaborative Design for a Finnish Teacher Education Development Programme. J. Teac. Educ. 2020, 9, 241-262.

4. Laurillard, D. The educational problem that MOOCs could solve: Professional development for teachers of disadvantaged students. Res. Learn. Technol. 2016, 24, 1-17. [CrossRef]

5. Kaul, M.; Aksela, M.; Wu, X. Dynamics of the Community of Inquiry (CoI) within a Massive Open Online Course (MOOC) for In-Service Teachers in Environmental Education. Educ. Sci. 2018, 8, 40. [CrossRef]

6. Matranga, A.; Silverman, J. An emerging community in online mathematics teacher professional development: An interactional perspective. J. Math. Teach. Educ. 2020. [CrossRef]

7. Castaño-Muñoz, J.; Kalz, M.; Kreijns, K.; Punie, Y. Who is taking MOOCs for teachers' professional development on the use of ICT? A cross-sectional study from Spain. Technol. Pedagog. Educ. 2018, 27, 607-624. [CrossRef]

8. Powell, C.G.; Bodur, Y. Teachers' perceptions of an online professional development experience: Implications for a design and implementation framework. Teach. Teach. Educ. 2019, 77, 19-30. [CrossRef]

9. Stuckey, M.; Hofstein, A.; Mamlok-Naaman, R.; Eilks, I. The meaning of 'relevance' in science education and its implications for the science curriculum. Stud. Sci. Educ. 2013, 49, 1-34. [CrossRef]

10. Krapp, A.; Prenzel, M. Research on interest in science: Theories, methods, and findings. Int. J. Sci. Educ. 2011, 33, 27-50. [CrossRef]

11. Herranen, J.; Vesterinen, V.-M.; Aksela, M. How to measure elementary teachers' interest in teaching chemistry? Chem. Educ. Res. Pr. 2015, 16, 408-416. [CrossRef] 
12. Aksela, M.; Vartiainen, J.; Tuomisto, M.; Turkka, J.; Pernaa, J.; Tolppanen, S. Promoting Meaningful Science Teaching and Learning Through ICT in the Finnish LUMA Ecosystem. In New Ways to Teach and Learn in China and Finland: Crossing Boundaries with Technology; Niemi, H., Jia, J., Eds.; Peter Lang: Frankfurt am Main, Germany, 2016; pp. 255-278.

13. Aksela, M.; Wu, X.; Halonen, J.E. Relevancy of the Massive Open Online Course (MOOC) about Sustainable Energy for Adolescents. Educ. Sci. 2016, 6, 40. [CrossRef]

14. Fore, G.A.; Feldhaus, C.R.; Sorge, B.H.; Agarwal, M.; Varahramyan, K. Learning at the nano-level: Accounting for complexity in the internalization of secondary STEM teacher professional development. Teach. Teach. Educ. 2015, 51, 101-112. [CrossRef]

15. Shulman, L. Knowledge and teaching: Foundations of the new reform. Harv. Educ. Rev. 1987, 57, 1-22. [CrossRef]

16. Kurup, P.M.; Li, X.; Powell, G.; Brown, M. Building future primary teachers' capacity in STEM: Based on a platform of beliefs, understandings and intentions. Int. J. STEM Educ. 2019, 6, 1-14. [CrossRef]

17. Darling-Hammond, L.; Hyler, M.E.; Gardner, M. Effective Teacher Professional Development; Learning Policy Institute: Palo Alto, CA, USA, 2017.

18. Van Aalsvoort, J. Activity theory as a tool to address the problem of chemistry's lack of relevance in secondary school chemistry education. Int. J. Sci. Educ. 2004, 26, 1635-1651. [CrossRef]

19. Sjøberg, S.; Schreiner, C. The ROSE Project: An Overview and Key Findings; University of Oslo: Oslo, Norway, 2010.

20. Misra, P. MOOCs for Teacher Professional Development: Reflections and Suggested Actions. Open Prax. 2018, 10 , 67-77. [CrossRef]

21. Dillahunt, T.; Wang, Z.; Teasley, S.D. Democratizing higher education: Exploring MOOC use among those who cannot afford a formal education. Int. Rev. Res. Open Dis. 2014, 15, 177-196. [CrossRef]

22. Reich, J. Rebooting MOOC research. Science 2015, 347, 34-35. [CrossRef] [PubMed]

23. Lambert, S.R. Do MOOCs contribute to student equity and social inclusion? A systematic review 2014-18. Comput. Educ. 2020, 145, 103693. [CrossRef]

24. Christensen, G.; Steinmetz, A.; Alcorn, B.; Bennett, A.; Woods, D.; Emmanuel, E.J. The MOOC Phenomenon: Who Takes Massive Open Online Courses and Why? 2013. Available online: http:/ / papers.ssrn.com/sol3/papers.cfm?abstract_id=2350964 (accessed on 30 March 2021).

25. Knapper, C. Does educational development matter? Int. J. Acad. Dev. 2016, 21, 105-115. [CrossRef]

26. Vivian, R.; Falkner, K.; Falkner, N. Addressing the challenges of a new digital technologies curriculum: MOOCs as a scalable solution for teacher professional development. Res. Learn. Technol. 2014, 22, 24691. [CrossRef]

27. Koukis, N.; Jimoyiannis, A. MOOCS for teacher professional development: Exploring teachers' perceptions and achievements. Interact. Technol. Smart Educ. 2019, 16, 74-91. [CrossRef]

28. Wambugu, P. Massive Open Online Courses (MOOCs) for Professional Teacher and Teacher Educator Development: A Case of TESSA MOOC in Kenya. Univers. J. Educ. Res. 2018, 6, 1153-1157. [CrossRef]

29. Reparaz, C.; Aznárez-Sanado, M.; Mendoza, G. Self-regulation of learning and MOOC retention. Comput. Hum. Behav. 2020, 111, 106423. [CrossRef]

30. Rafiq, K.R.M.; Hashim, H.; Yunus, M.M. MOOC for Training: A Review of The Variations Of MOOC. Int. J. Innov. Creat. Chang. 2019, 5, 90-98.

31. Warriem, J.M.; Murthy, S.; Iyer, S. Shifting the focus from Learner Completion to Learner Perseverance: Evidences from a Teacher Professional Development MOOC. In Proceedings of the 24th International Conference on Computers in Education, Bombay, India, 28 November-2 December 2016.

32. Bao, W. COVID-19 and online teaching in higher education: A case study of Peking University. Hum. Behav. Emerg. Technol. 2020, 2, 113-115. [CrossRef] [PubMed]

33. Hrastinski, S.; Keller, C.; Carlsson, S.A. Design exemplars for synchronous e-learning: A design theory approach. Comput. Educ. 2010, 55, 652-662. [CrossRef]

34. Østergaard, E.; Dahlin, B.; Hugo, A. Doing Phenomenology in Science Education. A Research Review. Stud. Sci. Educ. 2008, 44, 93-121. [CrossRef]

35. Baggaley, J. MOOC rampant. Distance Educ. 2013, 34, 368-378. [CrossRef] 